\title{
Hubungan Karakteristik Pasien Peserta BPJS dengan Tingkat Kepuasan Pasien Peserta BPJS terhadap Pelayanan Rawat Inap di Rumah Sakit Umum "X" di daerah Kendal
}

\author{
Fanny Ardhitunggal Hakim*, Chriswardani Suryawati** \\ *Rumah Sakit Darul Istiqomah Kendal \\ **Fakultas Kesehatan Masyarakat, Universitas Diponegoro, Semarang \\ Email : ardhitunggal@gmail.com
}

\section{ABSTRACT}

There are Hospital type $D$ in Kendal who want to improve the quality of services after cooperating with BPJS. Measuring the level of patient satisfaction there are 10 indicators developed by Linder, including accessibility; availability of resources; continuity of care; efficacy; finances; humaneness; information gathering; information giving; pleasantness of surroundings; quality.

The design of this study was cross sectional with a quantitative approach, the number of 120 samples by measuring the level of satisfaction between patient characteristics (age, sex; education; occupation; income; BPJS membership status) with 10 indicators developed by Linder-pelz.

The results showed most respondents are patients BPJS PBI participants with income $<1500000$. On average, patients are satisfied with the services of hospitalization. This study showed no significant relationship between satisfaction with gender $(p=0.304)$ and age $(p=0.346)$, there was a significant relationship between satisfaction with work, income, membership status of BPJS, and education ( $p=0.00)$.

Conclusions of this study is a significant relationship between work, income, membership status and education and there is no significant relationship between age and sex with satisfaction.

Keyword: patient satisfaction, patient characteristics, BPJS, 10 indicator

\section{PENDAHULUAN}

Kesehatan merupakan hak dasar yang penting bagi setiap warga di Negara manapun di dunia. Di Indonesia, kesehatan warga Negara diatur dalam Undang-Undang Nomor 36 tahun 2009 tentang kesehatan bahwa kesehatan ialah salah satu hak dasar manusia dan termasuk dalam bagian kesejahteraan warga Negara yang diterapkan dengan adanya suatu layanan kesehatan. Maka diperlukan suatu sistem yang mengatur supaya terlaksananya usaha untu memenuhi hak warga Negara supaya tetap hidup dengan pola hidup sehat, yakni dengan mengedepankan layananan kesehatan yang terjangkau seluruh lapisan masyarakat. ${ }^{1}$

Badan Penyelenggara Jaminan Sosial atau BPJS kesehatan adalah badan hukum publik yang berfungsi menyelenggarakan program jaminan kesehatan bagi seluruh masyarakat Indonesia termasuk di dalamnya warga asing yang bekerjadi Indonesia paling singkat 6 bulan. Peserta BPJS terdiri dari 
peserta bantuan iur (PBI) yang terdiri dari fakir miskin serta orang tidak mampu, dan golongan non PBI yang terdiri dari pekerja swasta dan warga Negara asing dan termasuk peserta dari peralihan ASKES. ${ }^{3}$ BPJS adalah badan milik publik, maka indikator keberhasilan BPJS Kesehatan atau program JKN sama seperti badan public lainnya, yakni tingkat kepuasan masyarakat. ${ }^{5}$ Kepuasan dinilai dari pelayanan yang dilakukan Rumah sakit yang telah bekerjasama dengan BPJS dan dokter yang menjadi subyeknya.

Pengukuran kepuasan pasien merupakan salah satu pendekatan untuk mengukur kualitas suatu pelayanan. Kepuasan merupakan perasaan senang/kecewa seseorang yang diperoleh dari kesan terhadap kinerja atau hasil suatu produk dengan harapan-harapannya. ${ }^{7}$ Kualitas pelayanan dapat dilihat dari sepuluh dimensi yang dikembangkan Linder-pelz (1982) dalam krowinski, bertujuan sebagai instrument untuk mengukur kualitas pelayanan dengan mengukur selisih antara harapan konsumen terhadap kinerja pelayanan dengan pelayanan yang sebenarnya. Ada sepuluh dimensi yang dapat diaplikasikan pada setiap penyedia jasa untuk mengukur kualitas pelayanan. Sepuluh dimensi yang diukur dari pelayanan tersebut adalah dimensi accessibility/convenience (tempat mudah dijangkau); availability of resources (pelayanan lengkap); continuity of care (perawatan yang dilakukan secara terus menerus, rutinitas tanpa jeda/ libur/ kekosongan); efficacy/outcomes of care (tingkat kesembuhan); finances (murah terjangkau seluruh masyarakat); humaneness (pelayanan tanpa membedakan status seseorang, seluruh lapisan masyarakat); information gathering (pengumpulan informasi); information giving (pemberian informasi); pleasantness of surroundings (ada tempat hiburan di lingkungan penyedia layanan kesehatan); quality/competence (kecakapan petugas, ketrampilan petugas yang professional). ${ }^{17}$

Salah satu Rumah Sakit Umum Swasta yang berada di wilayah kabupaten Kendal yang merupakan rumah sakit tipe D milik yayasan Islam Cabang Kaliwungu, yang mempunyai tugas melaksanakan upaya pelayanan kesehatan secara berdaya guna dan berhasil guna dengan mengutamakan upaya penyembuhan, pemulihan yang dilaksanakan secara serasi, terpadu dengan upaya peningkatan kesehatan pencegahan dan melaksanakan upaya rujukan dengan kapasitas 55 tempat tidur, sedangkan jumlah kayawan sebanyak sebanyak 122 orang yaitu terdiri dari 122 tenaga kesehatan. Rumah Sakit ini mulai melayani peserta JKN sejak maret $2017 .^{4}$

Sampai saat ini belum pernah dilakukan survey kepuasan kepada pasien di instalasi rawat inap. Keadaan yang seperti ini dapat mempengaruhi Bed Occupancy Rate (BOR). Bed Occupancy Rate (BOR) merupakan salah satu indicator kinerja Rumah Sakit, yang salah satunya dipengaruhi oleh tingkat kepuasan pasien. Dari data tahun 2015 diketahui bahwa Bed Occupancy Rate (BOR) total $58,42 \%$, pada tahun 2016 mengalami kenaikan menjadi $60,57 \%$. Menurut grafik Johnson, BOR standar adalah 75\%-80\%, sehingga belum mencapai standar. Length $O f$ Stay (LOS) adalah rata-rata lamanya dirawat, pada tahun 2015 diketahui 3,32 kemudian mengalami penurunan pada tahun 2016 menjadi 3,28. Sedangkan Turn Over Interval (TOI) pada tahun 2015 diketahu 2,40\%, mengalami penurunan pada tahun 2016 menjadi 2,24\%. Hal tersebut menunjukkan interval pemakaian tempat tidur lebih panjang. $^{2}$

Data komplain pasien terhadap RS tahun 2016 sebanyak 15 komplain meningkat menjadi 26 komplain pada akhir 2017. Peningkatannya dimulai sejak agustus yaitu sesudah RS menerima pasien JKN. Untuk itu, 
dapat disimpulkan bahwa penelitian tentang kepuasan pasien rawat inap dilakukan untuk memperbaiki kualitas pelayanan, sehingga kepuasan pasien akan meningkat. Penelitian ini dilakukan untuk mengetahui hubungan karakteristik pasien peserta BPJS dengan tingkat kepuasan pasien peserta BPJS terhadap pelayanan rawat inap di salah satu rumah sakit swasta di kabupaten Kendal.

\section{METODE PENELITIAN}

Desain penelitian ini cross sectional dengan pendekatan kuantitatif, dengan jumlah sampel sebesar 120. Pengambilan sampel penelitian ini menggunakan cross sectional. Data primer dikumpulkan langsung dari sumber data melalui wawancara dengan responden menggunakan instrument penelitian berupa kuesioner. Peneliti menggunakan 2 kuosioner dalam penelitian ini. Kuosioner yang pertama untuk mengetahui karakteristik responden, meliputi: nama, umur, jenis kelamin, pendidikan, alamat, pekerjaan, penghasilan, status kepesertaan BPJS, dan kelas perawatan, dan untuk mengetahui harapan pelayanan yang diterima pasien terhadap pelayanan rawat inap. Kuosioner yang kedua digunakan untuk mengetahui kepuasan pasien berdasarkan pengalaman pasien selama menerima perawatan rawat inap. Kuesioner yang digunakan, sebelumnya diuji validitas dan realibilitasnya. Analisis data yang dilakukan dengan metoda analisis kuantitatif dengan tahapan sebagai berikut :

1. Uji normalitas data untuk menilai suatu data tesrsebut berdistribusi normal atau tidak.

2. Analisis univariat untuk melihat karakteristik variabel independen dan variabel dependen.

3. Analisis bivariat dilakukan untuk melihat hubungan masing-masing variabel bebas dan variabelterikat dan bertujuan untuk melihat apakah ada hubungan bermakna atau tidak dengan menggunakan uji Chi-square.

4. Analisis multivariat dilakukan untuk mengetahui seberapa besar pengaruh variable bebas dan variable terikatnya.

\section{HASIL DAN PEMBAHASAN}

\section{Hubungan Karakteristik Pasien BPJS dengan Tingkat Kepuasan}

Tabel 1 Hubungan Karakteristik Pasien BPJS dengan Tingkat Kepuasan

\begin{tabular}{|c|c|c|c|c|c|}
\hline \multicolumn{2}{|c|}{ Karakteristik } & \multicolumn{2}{|c|}{ Kepuasan } & \multirow{2}{*}{$\begin{array}{c}\text { Nilai } \\
\mathrm{P}\end{array}$} & \multirow{2}{*}{ Kemaknaan } \\
\hline Karak & eristik & $\begin{array}{l}\text { Puas } \\
(\%)\end{array}$ & $\begin{array}{l}\text { Tidak } \\
\text { Puas (\%) }\end{array}$ & & \\
\hline \multirow[b]{2}{*}{$\begin{array}{c}\text { Jenis } \\
\text { Kelamin }\end{array}$} & Laki-laki & 15,8 & 84,2 & \multirow{2}{*}{0,224} & \multirow{2}{*}{$\begin{array}{l}\text { Tidak ada } \\
\text { hubungan }\end{array}$} \\
\hline & $\begin{array}{l}\text { Perempu } \\
\text { an }\end{array}$ & 32,5 & 67,5 & & \\
\hline \multirow[b]{2}{*}{ Usia } & Muda & 26,6 & 28,4 & \multirow{2}{*}{0,344} & \multirow{2}{*}{$\begin{array}{l}\text { Tidak ada } \\
\text { Hubungan }\end{array}$} \\
\hline & Tua & 31,4 & 33,6 & & \\
\hline \multirow{3}{*}{ Pekerjaan } & $\begin{array}{l}\text { Tidak } \\
\text { Bekerja }\end{array}$ & 11,6 & 12,4 & \multirow{2}{*}{0,000} & \multirow{2}{*}{$\begin{array}{c}\text { Ada } \\
\text { hubungan }\end{array}$} \\
\hline & Bekerja & 46,4 & 49,6 & & \\
\hline & $<150000$ & & & \multirow{3}{*}{0,000} & \multirow{3}{*}{$\begin{array}{c}\text { Ada } \\
\text { hubungan }\end{array}$} \\
\hline \multirow[b]{2}{*}{$\begin{array}{c}\text { Penghasil } \\
\text { an }\end{array}$} & 0 & 35,8 & 38,2 & & \\
\hline & $\begin{array}{l}>150000 \\
0\end{array}$ & 22,2 & 23,8 & & \\
\hline \multirow{2}{*}{$\begin{array}{l}\text { Pendidik- } \\
\text { an }\end{array}$} & Rendah & 18,4 & 19,6 & \multirow{2}{*}{0,000} & \multirow{2}{*}{$\begin{array}{c}\text { Ada } \\
\text { hubungan }\end{array}$} \\
\hline & Tinggi & 39,6 & 42,4 & & \\
\hline \multirow{2}{*}{$\begin{array}{c}\text { Status } \\
\text { Kepeserta } \\
\text { an }\end{array}$} & PBI & 35,8 & 38,2 & \multirow{2}{*}{0,000} & \multirow{2}{*}{$\begin{array}{c}\text { Ada } \\
\text { hubungan }\end{array}$} \\
\hline & Non PBI & 22,2 & 23,8 & & \\
\hline
\end{tabular}

Hasil analisis menunjukkan bahwa tidak ada hubungan antara usia dengan tingkat kepuasan. Hasil penelitian ini sama dengan hasil penelitian yang dilakukan oleh Sudarni pada tahun 2009, namun berbeda dengan hasil penelitian yang dilakukan oleh Dinawati pada tahun 2017. Hasil penelitian ini berbanding terbalik dengan perkiraan penulis, dimana dari data kependudukan kabupaten Kendal, penduduk dengan jenis kelamin laki-laki lebih banyak dibandingkan dengan perempuan. Jenis kelamin mempunyai pengaruh terhadap pandangan jasa pelayanan yang diberikan. Perempuan lebih menilai sesuatu secara detail dibandingkan laki-laki yang cenderung tidak peduli. ${ }^{38}$ sedangkan dari hasil analisis juga 
menunjukkan bahwa tidak ada hubungan antara usia dengan tingkat kepuasan. Hasil penelitian ini sama dengan penelitian yang dilakukan Dinawati pada tahun 2017, dimana dalam penelitiannya, usia yang paling dominan adalah usia tua. Penelitian yang dilakukan Coser pada tahun 1956 menyatakan bahwa seseorang dengan usia muda lebih agresif mencari informasi dan tidak menunjukkan sikap menyesuaikan diri. Oleh sebab itu, usia merupakan salah satu faktor yang mempengaruhi konsumen terhadap mutu kesehatan. ${ }^{35}$

Hasil analisis menunjukkan bahwa ada hubungan yang bermakna antara pekerjaan dengan kepuasan. Pekerjaan seseorang turut mempengaruhi penghasilannya. Sehingga pada pekerjaan penghasilan baik, cenderung akan membuatnya lebih banyak tuntutan, sehingga akan mempengaruhi tingkat kepuasannya. ${ }^{18} \mathrm{Hal}$ ini menunjukkan bahwa ada hubungan yang bermakna antara penghasilan dengan kepuasan. Hal ini sesuai dengan penelitian yang dilakukan Hidayati pada tahun 2014, semakin tinggi pendapatan seseorang, maka tingkat kepuasannya semakin rendah. Sesuai dengan pernyataan Azwar bahwa penelitian sebelumnya telah mengungkapkan semakin tinggi pendapatan pasien atau keluarga pasien maka semakin tinggi pula tuntutan pasien terhadap kemampuan petugas kesehatan. ${ }^{11}$ Hal inilah yang membuat para penyelenggara kesehatan terus berupaya meningkatkan mutu pelayanan kesehatan yang diberikan.

Hasil penelitian ini juga menunjukkan bahwa ada hubungan yang bermakna antara status kepesertaan BPJS dengan kepuasan. Hasil ini berbanding terbalik dengan penelitian Hadiati pada tahun 2014, dimana penanggung merasa tidak puas daripada tertanggung dan ini dikarenakan penanggung mempunyai kewajiban untuk membayar dan cenderung untuk menuntut pelayanan yang lebih baik.
Hasil analisis menunjukkan bahwa ada hubungan yang bermakna antara pendidikan dengan kepuasan. Terdapat pola hubungan yang negatif antara pendidikan dan layanan kesehatan. Semakin tinggi pendidikan seseorang, maka ia akan semakin memanfaatkan layanan kesehatan, sedangkan pada orang yang pendidikannya rendah cenderung bertahan untuk tidak memanfaatkan layanan kesehatan. Sehingga pada yang berpendidikan tinggi akan lebih kritisi dalam menerima layanan yang tidak sesuai dengan harapannya. Semakin tinggi pendidikan akan semakin tinggi keinginan untuk memanfaatkan pengetahuan dan keterampilan, juga akan memiliki kecenderungan untuk melakukan tuntutan, juga harapan yang lebih tinggi. Semakin tinggi tingkat pendidikan klien maka tingkat kepuasannya semakin rendah. Hal ini sangat beralasan, biasanya orang dengan pendidikan rendah tidak mempunyai harapan tinggi kepada orang lain atas dirinya. Sebaliknya, orang yang berpendidikan tinggi biasanya mempunyai harapan yang tinggi terhadap orang lain atas dirinya.

\section{KESIMPULAN}

Sebagian besar responden berjenis kelamin perempuan $(61,7 \%)$, dengan usia yang paling dominan adalah usia tua $(52,4 \%)$. Responden memiliki pendidikan rendah $(68,3 \%)$ dan bekerja (80\%) dengan penghasilan $<1500000(61,7 \%)$. Responden dengan status kepesertaan BPJS terbanyak dari golongan Penerima Bantuan Iuran $(61,7 \%)$.

Ada hubungan yang bermakna antara pekerjaan, penghasilan, status kepesertaan dan pendidikan serta tidak ada hubungan yang bermakna antara usia dan jenis kelamin dengan kepuasan. 


\section{UCAPAN TERIMA KASIH}

Penulis mengucapkan terima kasih kepada MIKM FKM UNDIP dan segenap direksi RS Muhammadiyah Darul Istiqomah Kendal atas diijinkannya melakukan penelitian ini.

\section{DAFTAR PUSTAKA}

1. Candra, Yoga. Manajemen Administrasi Rumah Sakit Edisi Ke-2, Jakarta : UI Press: 2010.

2. Yaqub, Ishaq. Kualitas Pelayanan Pasien Jasa Rawat Inap Kelas III Pada Rumah Sakit Umum Daerah Abdul Wahab Sjahranie Kota Samarinda. 2015; vol 3; no.4;1073-1084

3. Republik Indonesia. 2011. UndangUndang No. 24 Tahun 2011 tentang Badan Penyelenggara Jaminan Sosial. Sekretariat Negara. Jakarta.

4. Keperawatan RSDI. Laporan Kegiatan RSDI Kendal. Kendal : Rekam medis RSDI; 2017

5. Depkes RI. Buku Pegangan Sosialisasi Jaminan Kesehatan Nasional (JKN) dalam Sistem Jaminan Sosial Nasional (SJSN), Jakarta :2013

6. Rambat, Lupiyoadi. Manajemen Pemasaran Jasa, Jakarta. Salemba Empat: 2003

7. Kotler, Philip. Manajemen Pemasaran. Edisi millennium. prenhallindo. Jakarta: 2000

8. Rangkuti, Freddy. Measuring Customer Satisfaction: Teknik Mengukur dan Strategi Meningkatkan Kepuasan Pelanggan, Gramedia Pustaka Utama, Jakarta: 2003

9. BPJS Kesehatan (Badan Penyelenggara Jaminan Sosial. Panduan Layanan bagiPeserta BPJS Kesehatan[online], (diunduh 4 Desember 2016), tersedia dari: http://sappk.itb.ac.id/wpcontent/uploads/2014/01/Buku-Panduan-
Layanan-bagi-Peserta-BPJS-

Kesehatan.pdf 2013

10. Azwar.Menjaga Mutu Pelayanan Kesehatan Aplikasi Prinsip Lingkaran Pemecahan Masalah. Jakarta: Pustaka Sinar Harapan: 2007.

11. Dahlan, Sopiyudin. M. Besar Sampel dan Cara Pengambilan Sampel Dalam Penelitian Kedokteran dan Kesehatan. Jakarta: SagungSeto: 2010.

12. Dahlan, Sopiyudin. M. Statistik Untuk Kedokteran dan Kesehatan. Jakarta: Salemba 2012.

13. Kementerian Kesehatan RI. Buku Saku FAQ (Frewuently Asked Question) BPJS Kesehatan Cetakan Pertama. Kementrian Kesehatan RI, Jakarta : 2013.

14. Notoatmodjo. Metodologi Penelitian Kesehatan (edisi revisi). Jakarta: Rineka Cipta: 2010.

15. Bauhoff Sebastian. Responsiveness and satisfaction with providers and carriers in a safety net insurance program: Evidence from Georgia's Medical Insurance for the Poor. www.elsevier.com /locate/healthpol 2011

16. Bogner Hillary R. Patient Satisfaction and Prognosis for Functional Improvement and Deterioration, Institutionalization, and Death among Medicare Beneficiaries Over Two Years. Archives of Physical Medicine and Rehabilitation : 2016

17. Jacobalis. Kumpulan Tulisan Tentang Rumah Sakit di Indonesia dalam Dinamika Sejarah, Transformasi, Globalisasi dan Krisis Nasional, Yayasan Penerbit IDI. Jakarta: 2000

18. Jacobalis,S. Menjaga Mutu Pelayanan Rumah Sakit, Citra Windu Satria. Jakarta : 1989

19. Mpinga Emmanuel Kabengele. Satisfaction of patients: A right to health 
indicator.

www.elsevier.com

/locate/healthpol. 2011

20. Supardi S., Sakit dan Perilaku Sakit.

Cermin Dunia Kedokteran III.

Jakarta:1996

21. Coser, Lewis. Function Of Social

Conflict. Free Pree. New York : 1956. 